\title{
Common ground and grounds of law
}

\author{
Marat Shardimgaliev* \\ Department of Philosophy, University of Reading
}

\begin{abstract}
A central premise of Ronald Dworkin's famous Argument from Theoretical Disagreement is that judges regularly disagree about the grounds of law. The occurrence of these so-called 'theoretical disagreements', it is argued, cannot be explained by the influential legal positivist theory of HLA Hart according to which the grounds of law are constituted by judicial consensus. However, in his attempt to show that theoretical disagreements actually exist Dworkin primarily relies on the occurrence of judicial disagreements about legal interpretation, as he takes them to be disagreements about the grounds of law. In this article, I will argue that these interpretive disagreements do not pose a problem for Hartian positivism. My argument will rely on standard work from the field of pragmatics which provides sophisticated explanations of how the interpretation of linguistic texts, such as legal documents, works. On the model that I will propose, interpretive disagreements concern the meaning that the legal authorities who enacted the document intended to get across and these disagreements arise from diverging assumptions about the context in which these documents were enacted. I will argue that disagreements about intentions and contextual presumptions do not concern the grounds of law and therefore do not threaten Hartian positivism.
\end{abstract}

Keywords: legal interpretation, legal positivism, pragmatics, theoretical disagreement

\section{INTRODUCTION}

A fiercely debated question in contemporary jurisprudence concerns the extent to which Ronald Dworkin's Argument from Theoretical Disagreement (ATD) poses a threat to the influential legal positivist account of HLA Hart. ${ }^{1}$ According to the ATD, Hart's theory fails to explain what Dworkin calls 'theoretical disagreements' about law which are disagreements among the officials of a legal system about the 'grounds' or 'sources' of law of that system. These disagreements are said to pose a problem for Hart's theory because one of its central claims is that the grounds of law of a legal system are determined by a conventional rule that is shared by the officials of that

* I would like to thank the Australasian Society of Legal Philosophy (ASLP) for selecting an earlier version of this paper for the ASLP 2019 Essay Prize. The comments of the judging committee have been very helpful in the preparation of the final version. The paper has also benefitted from discussions at the Cambridge Doctoral Workshop in Legal Theory 2018 and the Graduate Research Seminar of the Philosophy Department at the University of Reading in the Autumn Term of 2019. Further, I am grateful to Emma Borg, Patrick Capps, Dimitrios Kyritsis, Antonio Scarafone and the editors of the Journal of Legal Philosophy for detailed written comments that have helped to improve the paper. My work was supported by the South, West and Wales Doctoral Training Partnership which is funded by the Arts and Humanities Research Council (Grant Number: AH/L503939/1).

1. Ronald Dworkin, Law's Empire (Belknap Press 1986) ch 1; HLA Hart, The Concept of Law (3rd edn, Oxford University Press 2012). 
system: the Rule of Recognition. More specifically, Dworkin argues that persistent theoretical disagreements are incoherent on Hart's theory because the theory postulates that judges who engage in a disagreement about whether something is a ground of law will conclude that it cannot be a ground of law since for it to be such a ground there would need to be conventional agreement among judges that this is so. However, it seems that this is not the conclusion that judges draw in such cases: despite continuous disagreement they insist that the grounds that they are relying on are the 'correct' ones. Many legal philosophers consider the ATD to pose a significant problem for Hart's theory and Scott Shapiro has even gone so far as to call it 'the most serious threat facing legal positivism at the beginning of the twenty-first century'. ${ }^{2}$ Confronted with Dworkin's challenge, positivists have made multiple attempts to explain theoretical disagreements in a way that is compatible with Hart's account but the extent to which these attempts have been successful remains highly contested. ${ }^{3}$

While this article does not purport to provide an explanation of all the cases of disagreement that Dworkin deems to be theoretical, I do intend to make some important progress in overcoming the challenge that the ATD poses for Hart's theory by providing an explanation of a type of disagreement that is central to Dworkin's account: disagreements about interpretation (or 'interpretive disagreements' for short). More specifically, my starting point will be the observation - made by a number of commentators - that rather than being about the status of certain texts as sources of law, 'the key theoretical disagreements for Dworkin concern the meaning of the acknowledged sources of law such as statutes and constitutional texts'. ${ }^{4}$ In other words, an important class of disagreements that Dworkin invokes against Hart is not about whether certain texts are grounds of law but whether these texts are correctly interpreted..$^{5}$ My proposal is to explain these interpretive disagreements by turning to the field of pragmatics - the study of language use in context - as it provides sophisticated theoretical accounts of meaning and interpretation. Thereby, I will try to link the recent disputes about theoretical disagreements to another recent and influential line of research in legal theory according to which the neglect of the pragmatic

2. Scott J Shapiro, 'The "Hart-Dworkin" Debate: A Short Guide for the Perplexed' in Arthur Ripstein (ed), Ronald Dworkin (Cambridge University Press 2007) 50.

3. See, notably, Matthew H Kramer, In Defense of Legal Positivism: Law Without Trimmings (Oxford University Press 1999) ch 6; Kenneth Einar Himma, ‘Ambiguously Stung: Dworkin's Semantic Sting Reconfigured' (2002) 8 Legal Theory 145; Brian Leiter, 'Explaining Theoretical Disagreement' (2009) 76 University of Chicago Law Review 1215; Dale Smith, 'Has Raz Drawn the Semantic Sting?' (2009) 28 Law and Philosophy 291; Tim Dare, 'Disagreeing about Disagreement in Law: The Argument from Theoretical Disagreement' (2010) 38(2) Philosophical Topics 1; Dale Smith, 'Theoretical Disagreement and the Semantic Sting' (2010) 30 Oxford Journal of Legal Studies 635; Hart, The Concept of Law (n 1) 257-59; Barbara Baum Levenbook, 'Dworkin's Theoretical Disagreement Argument' (2015) 10 Philosophy Compass 1; Dale Smith, 'Agreement and Disagreement in Law' (2015) 28 Canadian Journal of Law and Jurisprudence 183; Luìs Duarte d'Almeida, 'The Grounds of Law' in Wil Waluchow and Stefan Sciaraffa (eds), The Legacy of Ronald Dworkin (Oxford University Press 2016); Dennis Patterson, 'Theoretical Disagreement, Legal Positivism, and Interpretation' (2018) 31 Ratio Juris 260; Brian Leiter, 'Theoretical Disagreements in Law: Another Look' in David Plunkett, Scott J Shapiro and Kevin Toh (eds), Dimensions of Normativity (Oxford University Press 2019).

4. Leiter, 'Explaining Theoretical Disagreement' (n 3) 1217 (emphasis in original).

5. Shapiro, 'The "Hart-Dworkin” Debate' (n 2); Scott J Shapiro, Legality (Belknap Press 2011) ch 10; Patterson (n 3). 
aspects of legal discourse might lead to an impoverished understanding of legal texts. ${ }^{6}$ I will argue that a Hartian explanation of interpretive disagreements can be provided by drawing on insights from perhaps the most influential pragmatic theory that is currently available: the framework of pragmatics that has its roots in the seminal work of philosopher of language Paul Grice. ${ }^{7}$ I will argue that an application of this 'neo-Gricean' framework to interpretive disagreements can be used to show that they do not need to be treated as theoretical disagreements, i.e. as incoherent disagreements about the conventional Rule of Recognition. Rather, they can be understood as disagreements about the meaning of legal texts that arise from disagreements about the contexts in which these texts need to be understood, and such disagreements concern facts that judges can coherently disagree about. If my argument is successful, then a crucial type of disagreement that the ATD relies on can be shown to be unproblematic for Hart and thereby help to undermine the force of Dworkin's argument.

The article is divided into four sections. First, I provide a more detailed presentation of the ATD and explain Dworkin's notorious example of an allegedly theoretical disagreement: Riggs $v$ Palmer. ${ }^{8}$ Second, I explain the role of considerations of meaning and interpretation in the ATD, as well as how my account relates to previous

6. See, for example, Andrei Marmor, 'The Pragmatics of Legal Language' (2008) 21 Ratio Juris 423; Scott Soames; 'Interpreting Legal Texts: What Is, and What Is Not, Special about the Law' in Scott Soames (ed), Philosophical Essays Vol. 1: What It Means and How We Use It (Princeton University Press 2009); Scott Soames, 'Toward a Theory of Legal Interpretation' (2011) 6 New York University Journal of Law and Liberty 231; Richard Ekins, The Nature of Legislative Intent (Oxford University Press 2012); Robyn Carston, 'Legal Texts and Canons of Construction: A View from Current Pragmatic Theory' in Michael Freeman and Fiona Smith (eds), Law and Language: Current Legal Issues (Oxford University Press 2013); Stephen Neale, 'Convergentism \& the Nature of Law' (Legal Theory Workshop, UCLA School of Law, 14/03/2013); Andrei Marmor, The Language of Law (Oxford University Press 2014); Timothy Endicott, 'Law and Language', The Stanford Encyclopedia of Philosophy (Summer edn, 2016) $<$ https://plato.stanford.edu/archives/sum2016/entries/law-language/> accessed 15 July 2020; Matthew H Kramer, HLA Hart: The Nature of Law (Polity Press 2018). To be clear, I disagree with the suggestion of some of these theorists according to which pragmatics and philosophy of language can specify the legal norms that exist in a legal system without taking legal philosophy into account. For an influential critique of this type of view, see Mark Greenberg, 'Legislation as Communication? Legal Interpretation and the Study of Linguistic Communication' in Andrei Marmor and Scott Soames (eds), Philosophical Foundations of Language in the Law (Oxford University Press 2011). But since my proposal will be to use pragmatics in order to inform theorizing in legal philosophy rather than to replace it - a theoretical move that Greenberg declares to be appropriate (see Greenberg (n 6) 220) - the view expressed here is not at odds with this critique. For a similar assessment of Greenberg's view, see Kramer, HLA. Hart (n 6) 211. For a criticism of various other arguments that Greenberg presents, see Marmor, The Language of Law (n 6) 15-22. For some related issues, see (n 79).

7. Paul Grice, Studies in the Way of Words (Harvard University Press 1989). See also Stephen Schiffer, Meaning (Oxford University Press 1972); Herbert H Clark, Arenas of Language Use (University of Chicago Press 1992); Herbert H Clark, Using Language (Cambridge University Press 1996); Robert C Stalnaker, Context and Content: Essays on Intentionality in Speech and Thought (Oxford University Press 1999); Robert C Stalnaker, 'Common Ground' (2002) 25 Linguistics and Philosophy 701; Robert C Stalnaker, Context (Oxford University Press 2014). 8. Riggs v Palmer, 115 NY 506 (1889). 
positivist attempts to defend Hart's theory. Third, I present the neo-Gricean framework. Finally, I apply the framework to the ATD and illustrate how it can explain interpretive disagreements by providing an alternative analysis of Riggs.

\section{THE ARGUMENT FROM THEORETICAL DISAGREEMENT}

As presented by Dworkin, the target of the ATD is what he calls the 'plain-fact view' about law. ${ }^{9}$ He defines it as the view that 'law depends only on matters of plain historical fact' or, more specifically, that '[t]he law is only a matter of what legal institutions, like legislatures and city councils and courts, have decided in the past ...', such that 'questions of law can always be answered by looking in the books where the records of institutional decisions are kept'.${ }^{10}$ According to Dworkin, legal positivists are the main proponents of the plain-fact view and his argument is usually understood to be directed primarily at their theories, in particular the positivism of Hart. ${ }^{11}$ To understand the ATD as an objection to Hart's positivism it is therefore important to explain why Dworkin took Hart's theory to be a plain-fact view about law.

Here, we need to consider the perhaps most fundamental claim of Hart's theory, namely that law must be understood as the union of primary and secondary rules. ${ }^{12}$ Roughly, primary rules are rules that concern action: they determine, for instance, what kind of action is legally permitted and what kind of action is forbidden. To use one of Dworkin's examples: a primary rule of Californian law is that no one may drive faster than 55 miles per hour in California. ${ }^{13}$ On Hart's theory, primary rules owe their existence to certain social facts which are usually decisions by legal authorities - such as parliaments and courts - that have been promulgated, for instance, in the form of statutes or judicial decisions. Secondary rules, on the other hand, are rules about rules. ${ }^{14}$ The secondary rule that is at the centre of Hart's theory and that is claimed to be fundamental to a legal system is the Rule of Recognition. This rule determines the criteria that other rules - including primary rules - have to satisfy in order to be considered valid rules of the system. ${ }^{15}$ To illustrate this with Hart's main example, at least part of the Rule of Recognition of English law is that whatever the Queen enacts in Parliament is law. ${ }^{16}$ To translate this into more Dworkinian terminology: by determining the criteria that certain decisions or enactments have to satisfy in order to

9. Dworkin, Law's Empire (n 1) 6. I will present the ATD as it emerges from the first chapter of Law's Empire and I will not consider a more premature version of the argument that Dworkin presented in earlier work. See Ronald Dworkin, Taking Rights Seriously (Harvard University Press 1978). Presenting the argument on the basis of the first chapter is slightly complicated by the fact that the chapter also contains the famous Semantic Sting Argument which closely resembles the ATD. The Semantic Sting Argument objects to semantic theories of law which are theories that analyse the conventional meaning or use of the word 'law', see Dworkin, Law's Empire (n 1) 31-46. I will not discuss the Semantic Sting Argument in this context because Hart's theory is not a semantic account of law. See Hart, The Concept of Law (n 1) 246. See also Levenbook (n 3) 2; Kramer, HLA Hart (n 6) 207.

10. Dworkin, Law's Empire (n 1) 31, 7, 7.

11. ibid 33 .

12. Hart, The Concept of Law (n 1) ch 5.

13. Dworkin, Law's Empire (n 1) 4.

14. Hart, The Concept of Law (n 1) 94.

15. ibid 100-10.

16. ibid 107. The 'full' Rule of Recognition of English law is of course more complex and 
create legal rules, the Rule of Recognition determines the 'grounds' or 'sources' of law. ${ }^{17}$ Hence, if it is a criterion of legal validity that whatever the Queen enacts in Parliament is law, the Queen's enactments in Parliament are grounds of law.

As Hart explains, the main purpose of the Rule of Recognition is to remove uncertainty about the rules that exist in a legal system. ${ }^{18}$ More specifically, the criteria that the Rule of Recognition sets out serve as a test for ascertaining whether a rule is legally valid or not. It should be noted, though, that Hart emphasized that the Rule of Recognition does not remove all uncertainty about existing legal rules when he said that it 'is a misconception' to think that the Rule of Recognition

is meant to determine completely the legal result in particular cases, so that any legal issue arising in any case could simply be solved by mere appeal to the criteria or tests provided by the rule. ... The function of the rule is to determine only the general conditions which correct legal decisions must satisfy in modern systems of law. ${ }^{19}$

In contrast to primary rules and other secondary rules, as a fundamental rule the Rule of Recognition does not rest upon a decision by a legal authority but on a shared conventional practice among legal officials. ${ }^{20}$ Nonetheless, what the Rule of Recognition of a legal system is, is still a matter of fact because it is a matter of fact what the conventional practice of the legal officials of a system is. In Hart's own words: 'the rule of recognition exists only as a complex, but normally concordant, practice of the courts, officials, and private persons in identifying the law by reference to certain criteria. Its existence is a matter of fact'. ${ }^{21,22}$ Hence, because both primary and secondary rules are matters of fact, Dworkin considers Hart's account to be a plain-fact view about law.

Admittedly, this is only a rough outline of Hart's analysis of law in terms of primary and secondary rules, but it should be sufficient to explain Dworkin's argument and the way it purports to undermine Hart's account. ${ }^{23}$ According to the

includes, for example, that judicial decisions are sources of law and that common law is subordinate to statutory enactment. See Hart, The Concept of Law (n 1) 101, 110.

17. Dworkin, Law's Empire (n 1) 4, 39.

18. Hart, The Concept of Law (n 1) 94.

19. ibid 258,258 . In this context he also wrote that 'the exclusion of all uncertainty at whatever costs in other values is not a goal which I have ever envisaged for the rule of recognition'. Hart, The Concept of Law (n 1) 251.

20. ibid 266-67.

21. Matthew Kramer has criticized Hart for suggesting that the existence of the Rule of Recognition depends on the practices of ordinary citizens. See Kramer, HLA Hart (n 6) 78-81. He explains that although ordinary citizens can be aware of the Rule of Recognition and display their awareness in their conduct, what is truly constitutive of a Rule of Recognition is the practice of legal officials.

22. Hart, The Concept of Law (n 1) 110. Hart makes the conventional aspect of the Rule of Recognition more explicit in his Postscript: 'Certainly the rule of recognition is treated in my book as resting on a conventional form of judicial consensus'. Hart, The Concept of Law (n 1) 266-67.

23. To avoid misunderstanding I must highlight at least two ways in which this outline is imprecise. First, Dworkin's characterization of Hart's view as a plain-fact view is not quite accurate, as Hart himself has pointed out in his Postscript, see Hart, The Concept of Law (n 1) 247-48. Hart argues that his theory does not only permit facts, such as legislative enactments, to constitute sources of law but that it can also be 'principles of justice or substantive moral values' as long as they are validated by the Rule of Recognition. Hart, The Concept of Law (n 1) 247. 
ATD, Hart's theory fails to explain persistent disagreements about the grounds of law. ${ }^{24}$ Dworkin claims that on Hart's view such disagreements are incoherent because judges who engage in a disagreement about the grounds of law would have to conclude that what they claim to be grounds of law cannot be grounds of law after all, because their dispute would show that there is no shared convention among them that this is so. However, it seems that this is not what legal officials do. Even in the face of disagreement they insist that they are appealing to the right sources. Before illustrating with one of Dworkin's examples that judges do seem to disagree about the grounds of law in this way, I must emphasize that Dworkin does not claim that all disagreements about law among legal officials are problematic for Hart. More specifically, he distinguishes disagreements about the grounds of law from so-called 'empirical disagreements'. ${ }^{25}$ As opposed to theoretical disagreements empirical disagreements occur when officials agree about the grounds of law 'but disagree about whether those grounds are in fact satisfied in a particular case' ${ }^{26}$ On the plain-fact view empirical disagreements are disagreements about a particular kind of fact, namely whether an authority whose enactments or decisions are accepted as grounds of law has in fact made and promulgated a particular decision. Dworkin illustrates this distinction with his example of a Californian law setting the speed limit at 55 miles per hour. ${ }^{27}$ Judges can disagree about whether this is law in two ways. First, judges can agree about the sources of law, i.e. agree that the source that would determine speed limits in California is an enactment by a legal authority as recorded in an official statute book but disagree whether the authorities have actually enacted such a statute. For instance, they might simply disagree about whether the book contains such a statute. This is an empirical disagreement. But judges might also disagree in a second way. They might disagree whether the respective statute in a Californian statute book actually is a source of law. This would be a theoretical disagreement. As Dworkin points out, '[e]mpirical disagreement about law is hardly mysterious' because '[p]eople can disagree about what words are in the statute books in the same ways as they disagree about any other matter of fact' ${ }^{28}$ However, Dworkin claims that 'theoretical disagreement in law, disagreement about law's grounds, is more problematic', in particular if one holds the view that 'lawyers and judges all actually agree

Although this is an important aspect of Hart's theory, which characterizes it as a 'soft', rather than a 'hard' version of legal positivism (see Hart, The Concept of Law (n 1) 250), I will not consider it further because it does not help him in refuting the ATD. See Shapiro, Legality (n 5) 286. Second, on Hart's view primary rules do not always require promulgation or communication by a legal authority, most notably because they can arise from custom. Hart, The Concept of Law (n 1) 26, 44-45. However, since disagreement about customary law does not seem to play any important role in the ATD, I will not consider it in the following. However, for Dworkin's critique of Hart's treatment of customary law, see Dworkin, Taking Rights Seriously (n 9) 41-43. For an account on the specific problems relating to the interpretation of this source of law, see also Frederick Schauer, 'Pitfalls in the Interpretation of Customary Law' in Amanda PerreauSaussine and James Bernard Murphy (eds), The Nature of Customary Law (Cambridge University Press 2007). I need to emphasize this here because my proposed account is only meant to apply to disagreements about authoritative decisions that have been communicated.

24. Dworkin, Law's Empire (n 1) 37-38.

25. ibid 5 .

26. ibid 4 .

27. ibid 4-5.

28. ibid 5 . 
about the grounds of law'. ${ }^{29}$ Theoretical disagreements would be problematic for Hart because they are disagreements about a type of fact about which disagreement cannot coherently persist: conventional practice.

To support his claim that theoretical disagreements among legal officials do actually occur, Dworkin presents a handful of cases in which legal officials have supposedly engaged in such a disagreement and he suggests that they are indicative of the frequent occurrence of this phenomenon. ${ }^{30}$ To provide an illustration of the kind of example that Dworkin invokes in his argument, I will consider Riggs, the case that he has relied on throughout his career to argue against positivism. ${ }^{31}$ The relevant facts of this case, which he calls 'Elmer's case', were as follows. ${ }^{32}$ Elmer Palmer poisoned his grandfather in New York in 1882 because he feared that instead of leaving him his estate after his death as set out in the grandfather's will, the grandfather would change his will due to his recent remarriage and leave Elmer nothing. Elmer's crime was discovered, and he was sentenced to a term of imprisonment. Nonetheless, he insisted that he was legally entitled to inherit because he took the will to be valid under the prevailing statutes of wills. These statutes regulate the form that a will has to take in order to be considered legally valid. The daughters of Elmer's grandfather who would have been entitled to the estate in case Elmer had died before him opposed the claim and argued that he had no right to inherit because he had killed the testator. However, as Dworkin explains, the 'statutes of wills ... said nothing explicit about whether someone named in a will could inherit according to its terms if he had murdered the testator'. ${ }^{33}$ Hence, Elmer's lawyer argued that the will satisfied all the formal criteria 'and that, therefore, it must have effect according to the letter of the law' ${ }^{34}$ The case led to a disagreement among the judges who had to decide it. Judge Gray, who wrote the dissenting opinion, held that judges should use what Dworkin calls a 'literal' method of legal interpretation - or what is nowadays perhaps more commonly known as a 'textualist' method. ${ }^{35}$ Dworkin describes this method as follows:

[T] he words of a statute [should] be given what we might ... call their acontextual meaning, that is, the meaning we would assign them if we had no special information about the context of their use or the intentions of their author. This method of interpretation requires that no context-dependent and unexpressed qualifications be made to general language ... ${ }^{36}$

Because the language of the statute did not make any explicit exceptions for a case such as Elmer's, Gray argued that he was entitled to inherit. Judge Earl, on the other hand, who argued for the majority, employed a method that gives effect to the intentions of the legislators and is accordingly known as 'intentionalism'. According to Dworkin, he argued that '[i]t would be absurd to suppose that the New York

29. ibid 5,7 .

30. ibid $15-30$.

31. Riggs (n 8); Dworkin, Taking Rights Seriously (n 9); Dworkin, Law's Empire (n 1); Ronald Dworkin, Justice in Robes (Belknap Press 2006).

32. Dworkin, Law's Empire (n 1) 15.

33. ibid 16.

34. Riggs (n 8) 509.

35. Dworkin, Law's Empire (n 1) 17; Antonin Scalia, 'Common Law Courts in a Civil Law System: The Role of United States Federal Courts in Interpreting the Constitution and Laws' in Amy Gutman (ed), A Matter of Interpretation: Federal Courts and the Law (Princeton University Press 1997) 23.

36. Dworkin, Law's Empire (n 1) 17-18. 
legislators who originally enacted the statute of wills intended murderers to inherit ...' and therefore decided that Elmer has no legal entitlement to the estate. ${ }^{37}$ Further, Earl supported his interpretation by arguing 'that statutes should be constructed from texts not in historical isolation but against the background of ... general principles of law'. ${ }^{38}$ The general principle which Earl held to be relevant in this particular case was that no one should profit from his own wrong which, when applied to Elmer's case, of course meant that he was not entitled to inherit.

The important point for our purposes is that on Dworkin's understanding there was a theoretical disagreement in Riggs. At different points he characterizes it as 'a dispute about what the law was, about what the real statute the legislators enacted really said' as 'disagreement ... about what the statute required when properly read' or as disagreement about what 'the text of the statute ... actually means' ${ }^{39}$ Put in terms of grounds of law, according to Dworkin the disagreement must have been about whether it is the literal meaning of a certain statute that is the ground of law and determines what the law 'actually means', or whether it is a certain kind of intention, or whether it might also be a general legal principle. It is also widely known that such disagreements have long persisted among legal officials. Hence, if they are really disagreements about the grounds of law, then there is no shared convention among legal officials that this is so. But if there is no such convention, then Hart cannot explain why judges persistently disagree about whether they are grounds of law because his theory requires that judges will conclude that they cannot be grounds of law.

\section{DISAGREEMENT AND INTERPRETATION}

As noted in the beginning, numerous theorists have attempted to provide an explanation of the disagreements that Dworkin invokes that is consistent with Hart's theory but the current state of the debate seems to be that none of the proposed explanations is dispositive with regards to the ATD. ${ }^{40}$ Due to limitations of space and the fact that an excellent critical overview of many of these proposals and their problems has recently been provided by Barbara Baum Levenbook I will not aim at providing a comprehensive survey or critique of the already existing literature. ${ }^{41}$ Important in that

37. ibid 19.

38. ibid 19.

39. ibid 20, 16, 16. All emphases have been added.

40. See the works cited in (n 3 ).

41. Levenbook ( $\mathrm{n} 3$ ). The more prominent recent contributions to the debate that have not been covered in her survey include Smith, 'Agreement and Disagreement in Law' (n 3); Duarte d'Almeida (n 3); Patterson (n 3); Leiter, 'Theoretical Disagreement in Law' (n 3). Levenbook's own paper is primarily aimed at surveying the literature and the explanation that she offers in that paper remains rather sketchy. The same goes for Patterson who acknowledges himself that he has only provided the 'basic contours' of a response to Dworkin and that 'much work remains'. Patterson (n 3) 274. For a persuasive critique of Duarte d'Almeida's account - which relies heavily on an interpretation of Hart made prominent by Kevin Toh (Kevin Toh, 'Jurisprudential Theories and First-Order Legal Judgments' (2013) 8 Philosophy Compass 457; Kevin Toh, 'Erratum to: Four Neglected Prescriptions to Hartian Legal Philosophy' (2015) 34 Law and Philosophy 333) - see Leiter, 'Theoretical Disagreement in Law' (n 3). (For further remarks on Duarte d'Almeida's proposal, see (n 80) and for a forceful critique of Toh's interpretation of Hart, see Kramer, HLA Hart (n 6). Here Leiter also responds to some of the objections that have been raised against his earlier work on the topic, but he does not sufficiently address the worry 
regard is also that the motivation behind my account is not so much to compete with existing proposals or to provide an explanation that is necessarily supposed to cover all cases of disagreement that Dworkin and other critics might deem to be theoretical. Rather, I believe that the different cases that they consider to be instances of theoretical disagreements might require different explanations because they are about different issues. I think of my proposal as a supplement to the explanatory toolkit of already existing proposals rather than as a competitor. For instance, while Riggs and other cases concern questions of statutory meaning and interpretation, ${ }^{42}$ Dworkin also invokes judicial disputes that are supposedly about the grounds of constitutional law ${ }^{43}$ or the relevance of policy considerations in case law. ${ }^{44}$ And although it would surely be preferable to have a single positivist explanation that can plausibly make sense of the whole variety of these cases, it is far from obvious that such an explanation is available. Scepticism with regards to the prospects of finding such a one-size-fits-all explanation is amplified by the fact that recent proposals that have tried to provide such an explanation have been persistently criticised for only being able to explain some cases but not others. ${ }^{45}$ In the absence of such an explanation, I suggest that positivists are well-advised to equip themselves with different explanatory tools that they can use when faced with cases of theoretical disagreement (or apparent theoretical disagreements). In some cases, disagreements might be explained as resulting from the disingenuousness or errors of judges. ${ }^{46}$ Other cases might be explained as disagreements about borderline issues. ${ }^{47}$ On other occasions it might simply be that Dworkin or others misrepresent the case in question. ${ }^{48}$ And yet other cases might call for other types of explanations. Nonetheless, for reasons that I will explain now, I believe that the explanation that I will provide can account for a class of cases that is central to Dworkin's argument.

that his proposal to explain theoretical disagreements generally as instances of disingenuousness or error is 'uncharitable in the extreme'. Shapiro, Legality (n 5) 290. Further, Leiter neither addresses the problem that his account fails to show that there is not much unexpressed or 'covert' theoretical disagreement in legal practice nor the problem that he fails to show that Hart's theory is overall superior to Dworkin's theory as a general theory of law. See Smith, 'Agreement and Disagreement in Law' (n 3) 183. There have also been other contributions to the debate which are rarely considered in the mainstream literature, such as Tim Dare's proposal to place the required agreement not at the level of the Rule of Recognition but at the level of more basic 'procedures'. See Dare (n 3). However, Dare's notion of procedures remains underdeveloped and it is therefore far from clear that his procedures could play the same role as the Rule of Recognition or that there could not be similar disagreements at the level of procedures. For a positivist approach that accepts that Hart's account cannot deal with the ATD, and that takes it as a reason to develop an alternative positivist approach, see Shapiro, Legality (n 5).

42. For another clear instance of disagreement about statutory meaning that is invoked by Dworkin, see Tennessee Valley Authority v Hill 437 US 153 (1978). The other disagreements that he presents (see the following notes) also arguably have a dimension of disagreement about meaning and interpretation.

43. Brown v Board of Education of Topeka, 347 US 483 (1954).

44. McLoughlin v O'Brian [1983] 1 AC 410.

45. See, notably, Smith, 'Has Raz Drawn the Semantic Sting?' (n 3); Smith, 'Theoretical Disagreement and the Semantic Sting' (n 3); Levenbook (n 3).

46. Leiter, 'Explaining Theoretical Disagreement' (n 3); Leiter, 'Theoretical Disagreements in Law' (n 3).

47. Kramer, In Defense of Legal Positivism (n 3) ch 6.

48. Himma (n 3). 
As noted in the beginning, the main observation that I take as a starting point is that many of Dworkin's examples are about the correct interpretation of legal texts. More specifically, it seems that in these cases judges do not disagree about which texts to consider when deciding a case, but rather about how these texts must be understood. As Dworkin says himself, the dispute in Elmer's case was not about the status of the New York statutes of wills as a source of law but about the correct interpretation of these statutes, 'about what the real statute the legislators enacted really said', 'what the statute required when properly read' or '[what] the text of the statute ... actually means' ${ }^{49}$ Hence, it seems that the disagreements in Dworkin's sample cases are often about the meaning of the applicable law which result from disagreements about the correct interpretive methods (Dworkin calls them 'theories' or 'styles' of interpretation) that need to be employed. ${ }^{50}$ As indicated above, this observation is not new but has already been made by commentators such as Leiter who writes that 'the key theoretical disagreements for Dworkin concern the meaning of the acknowledged sources of law ...' or Shapiro who even goes so far as to characterize the ATD exclusively in terms of disagreements about interpretive method. ${ }^{51}$

Based on this observation, some positivists claim that if interpretive disagreements can be explained within a Hartian framework then the ATD will no longer be a problem for his account. Perhaps the most recent claim to that effect comes from Dennis Patterson who writes that '[o]nce we understand how interpretation in law works, the problem of TD [theoretical disagreement] will simply fade away' and that 'one plausible explanation for the staying power of the debate over TD is the fact that positivists have simply failed to mount a credible account of legal interpretation'. 52 While, as indicated above, I am not sure whether it will always be sufficient only to consider interpretive disagreements, I think that these remarks at least clearly indicate that considerations of interpretation play a crucial role in Dworkin's argument and that therefore a lot of ground might be gained if Hartian positivism could explain interpretive disagreements. ${ }^{53}$

However, before I attempt to provide such an explanation, I want to say a couple of words about why theorists believe that disagreements about interpretive methodology pose a problem for Hart. For one might wonder: if the disagreements are not about which enacted texts should be considered but about how these texts should be interpreted, then why would we think that they are theoretical disagreements in the

49. Dworkin, Law's Empire (n 1) 20, 16, 16.

50. ibid 17.

51. Leiter, 'Explaining Theoretical Disagreement' (n 3) 1217. Shapiro writes:

The plain fact view ... claims that interpretive methodology is determined by the methodology accepted by all legal officials in a particular system. The problem with the plain fact view, as Dworkin points out, is that it rules out the possibility of meta-interpretive disputes. If officials disagree about interpretive methodology, then according to the plain fact view, there exists no proper methodology. However, since meta-interpretive disagreements are not only possible but common, the plain fact view cannot be a correct meta-interpretive theory. This is the argument from theoretical disagreement.

Shapiro, Legality (n 5) 305-06).

52. Patterson (n 3) 271.

53. Relevant here is also that an important general shortcoming of Hart's theory is that it fails to pay sufficient attention to matters of legal interpretation. As Kramer laments in his recent book-length study of Hart's account, 'a satisfactory theory of law has to include a much better account of legal reasoning and interpretation than the account offered by Hart in The Concept of Law'. Kramer, HLA Hart (n 6) 205. 
first place, given that theoretical disagreements are disagreements about sources of law? This question has recently been addressed by Leiter in reaction to a proposal by Tim Macklem:

Tim Macklem presses on me a different kind of positivist response: namely, that a Rule of Recognition identifies the sources of law, but does not adjudicate among all the ways of interpreting them. Here I agree, I take it, with Dworkin (as well as Shapiro): namely, that this austere conception of the RR [Rule of Recognition] would be inadequate to discharge the functions of an RR as Hart originally conceived them, namely, eliminating some (if not all) uncertainty about the valid legal norms are [sic] in a particular system. I thus agree (infrequent as that may be) with Dworkin that saying the duly enacted statute is a source of law is not enough for a RR that resolves uncertainty: it is necessary that the RR provide guidance as to what norms the statute enacts as legally valid. ${ }^{54}$

According to Leiter and, as he notes, also Shapiro and Dworkin, the Rule of Recognition must specify a method (or at least criteria) of interpretation because it would fail to serve its function of removing uncertainty about primary legal norms if it did not do so. The idea seems to be that without such a method there would be no way of distinguishing an appropriate from an inappropriate interpretation and therefore no guidance concerning the primary rules or norms that the texts give rise to. Note, however, that this does not require that the Rule of Recognition removes all uncertainty about the legal rules that obtain. Despite Leiter's ambivalent attitude towards the issue, we have seen that the function of the Rule of Recognition can be discharged 'as Hart originally conceived' it if it does not determine a clear result in all cases. Nonetheless, on this line of thought it is necessary that at least some guidance is provided towards interpretation, for if there were no criterion that determined what an appropriate interpretation is, every interpretation would be appropriate, and this would leave us entirely in the dark about the existing rules.

As I will explain in the fourth section, I disagree with this line of thought. Roughly, the reason is that I reject the idea that a conventional method of interpretation is necessary in order to determine the meaning of a text and the rule that it gives rise to. However, in order to explain why this is so, I will first need to introduce the neo-Gricean theory of meaning and interpretation.

\section{THE NEO-GRICEAN THEORY OF MEANING AND INTERPRETATION}

Given that Dworkin's argument turns to a significant extent on questions of meaning and interpretation, I suggest making use of pragmatics when facing up to the ATD. This seems prima facie promising because pragmatics provides sophisticated theoretical frameworks that explain what meaning is and how interpretation works. Admittedly, this suggestion is not new but has already been hinted at by Timothy Endicott in recent work:

To meet Dworkin's challenge, it is necessary to explain how it can be reasonable to disagree over the application of rules made by communicative acts. How can competent and (let's presume) sincere and reasonable adjudicators differ ... on the question of what the law allows or prohibits? The potential for such a reasonable disagreement (even among people who

54. Leiter, 'Theoretical Disagreements in Law' (n 3) 251. To my knowledge, Macklem's proposal has not been published. 
understand the language of the lawmaker equally well) is very readily to be found in ... complex pragmatic considerations ... 55

Endicott claims further that Dworkin's 'argument was based on an impoverished view of the controversy that can result from communication' which is due to the fact that Dworkin failed to take insights from pragmatics on board. ${ }^{56}$ However, Endicott himself does not make any detailed attempt at explaining how exactly a pragmatic explanation of interpretive disagreements might look and how it would apply to specific cases. The current article can thus be viewed as an attempt to cash out Endicott's insight.

The explanation that I want to propose is based on possibly the most influential theory that is currently available from the field of pragmatics: the so-called "neoGricean' framework of pragmatics that has its roots in the work of Paul Grice. ${ }^{57}$ More specifically, I will focus primarily on Grice's theory of meaning and the theory of interpretation that has been developed out of it. ${ }^{58}$ Grice's theory of meaning does not only suggest itself here because of its influence but also because it has been explicitly endorsed by Hart on several occasions, even if he did not put it to use when developing his theory of law. ${ }^{59}$ Grice's theory explains the meaning of a communicative contribution such as an utterance (but also non-verbal communicative acts) in terms of what the speaker means when making this utterance. This speaker meaning is analysed in terms of a specific intention on the side of the speaker, a so-called communicative intention. ${ }^{60}$ More precisely, a speaker means something by making an utterance if and only if she has the intention to produce an effect in an audience by means of her audience's recognition of this very intention. ${ }^{61}$ What the speaker means is specified by the intended effect. This might be, for instance, that the audience comes to believe a certain proposition or that the audience comes to intend to perform a certain act. Crucial features of the notion of a communicative intention are that it needs to be reflexive and transparent. It is reflexive because the speaker intends the effect to be produced through the audience's recognition of her intention to produce this effect

55. Endicott (n 6) para 2.4.

56. ibid para 2.4 .

57. See the works cited in (n 7). Despite its wide-ranging influence, this theoretical framework is not beyond controversy. For a recent survey of challenges and a defence of the framework, see Kasia Jaszczolt, 'Rethinking Being Gricean: New Challenges for Metapragmatics' (2019) 145 Journal of Pragmatics 15.

58. The other major pillar of Grice's theory is his theory of implicature. For an influential discussion of the theory of implicature in relation to legal discourse, see Marmor, 'The Pragmatics of Legal Language' (n 6); Marmor, The Language of Law (n 6). For my own discussion of Grice's theory of implicature in relation to legal discourse (with a particular focus on judicial opinions), and a critical assessment of Marmor's account, see Marat Shardimgaliev, 'Implicatures in Judicial Opinions' (2019) 32 International Journal for the Semiotics of Law 391.

59. HLA Hart, 'Signs and Words' (1952) 2 The Philosophical Quarterly 59, 61; HLA Hart, Essays on Bentham: Studies in Jurisprudence and Political Theory (Clarendon Press 1982) 244; Hart, The Concept of Law (n 1) 281. It is quite interesting that Hart used the Gricean theory of meaning in an early and rarely considered review of John Holloway's book Language and Intelligence (see Hart, 'Signs and Words' (n 59)) even before Grice had published his seminal paper 'Meaning' in 1957. After outlining an intention-based analysis of meaning Hart acknowledges in a footnote: 'Mr. P. Grice first made this clear to me'. Hart, 'Signs and Words' (n 59) 61. 60. Grice's own label was 'm-intention'. Grice (n 7) ch 14.

61. ibid 220. 
and it is transparent because this reflexive intention needs to be (made) clear to the addressee. The conditions that communicative intentions must satisfy distinguish them from other kinds of intentions, in particular intentions which are not intended to be recognized. For instance, while by saying 'I have to work' I might intend you to form the belief that I have to work by recognizing this very intention of mine, i.e. express a communicative intention, I might also have a variety of other intentions that I do not intend you to recognize, for instance that I intend to have a light dinner today or that I want to survive the next five minutes or that I want our conversation to be over as soon as possible. Although the speaker might have such unrelated, mundane or secret intentions they are not communicative intentions because the speaker does not intend them to be recognized by the addressee through some communicative act. Accordingly, in the following I will refer to all intentions that are not communicative as 'non-communicative intentions'.

Before explaining how this relates to questions of interpretation, I must briefly emphasize two central points about Grice's account of meaning. The first is that on Grice's account meaning is a matter of fact. This is so because it analyses meaning in terms of communicative intentions and their content. And since it is a matter of fact whether and what a speaker intends, it is also a matter of fact what a speaker means. The second point is that Grice's account is a general or universal account of meaning. ${ }^{62}$ More specifically, Grice's analysis of meaning is not supposed to capture the conventional conception of meaning of a specific community - something that might be different elsewhere - but to explain the very concept of meaning. It is a theory of meaning in the same sense in which Hart's theory is a theory of law.

Given that the meaning of a communicative contribution is determined by the communicative intention of the speaker, the interpretation of such contributions consists in the attempt to correctly recognize this intention. But how are the communicative intentions of speakers recognized? An answer to that question has been offered by neo-Griceans such as Herbert Clark and Robert Stalnaker and it is based on the crucial observation that '[c]ommunication, whether linguistic or not, normally takes place against a background of beliefs or assumptions which are shared by the speaker and his audience, and which are recognized by them to be so shared' ${ }^{63}$ This set of shared background assumptions is commonly labelled the 'common ground' and it characterizes the often used but rarely explained notion of the context of a conversation. ${ }^{64}$ The common ground is the information that interlocutors take for granted or presuppose as the shared background knowledge in their exchange. That we usually do take a lot for granted in conversation is very intuitive: depending on the situation we presuppose that our conversation partners know, for instance, that Berlin is the capital of Germany, that Kant was a philosopher, that in English the term 'house' and in French 'maison' is used to refer to houses, etc. This illustrates that the common ground may contain very different types of information. For instance, it can contain information about the conventional meaning of words and the grammar of a certain language such as English or French, information that has previously been exchanged

62. Max Black, 'Meaning and Intention: An Examination of Grice's Views' (1973) 4 New Literary History 257, 257.

63. Stalnaker, Context and Content (n 7) 48. See also the other works cited in (n 7).

64. Although already used by Grice in his 1967 William James lectures, the notion of common ground has become first well-known to philosophers of language under the label 'common knowledge' through David Lewis' famous analysis of conventions. David Lewis, Convention: A Philosophical Study (Harvard University Press 1969). 
in conversation, common-sense, etc. It might also contain information about the non-communicative intentions and attitudes of interlocutors, for instance the mundane information that people usually have the intention to survive the next five minutes. ${ }^{65}$

As Stalnaker explains, shared contextual information is crucial for communication in two ways: '[there are] two different roles that context plays: it is both the object on which speech acts act and the source of information relative to which speech acts are interpreted' ${ }^{66}$ That is, in communication interlocutors try to make the context richer, i.e. make this information common ground, but at the same time they also exploit the information that is already common ground in order to interpret a communicative act and to make themselves understood. ${ }^{67}$ Hence, the common ground is both end and means of communication. ${ }^{68}$ For illustration, consider a simple utterance such as (1):

(1) Peter went to London.

The aim of the speaker when making this utterance is to share the information - to make it common ground - that Peter went to London, but she also exploits already shared information to get this across. For instance, she must assume that her addressee speaks English, that there is a salient Peter in the common ground, that there is a salient London in the common ground, etc. This shows how common ground is relevant to recognizing (or understanding or interpreting) what a speaker meant, i.e. her communicative intention, when making an utterance. The audience recognizes the communicative intention by considering the speaker's utterance in the light of the shared information against which it is intended to be understood. ${ }^{69}$

Working with this theory of interpretation, neo-Griceans have successfully explained a broad variety of communicative phenomena which range from basic aspects of meaning such as reference, to sophisticated communicative manoeuvres such as the deception of overhearers to a conversation. ${ }^{70}$ The theory also contains the ingredients for an explanation of disagreements about meaning, but before I come to this, I would like to make three clarificatory points about the theory and the notion of presupposition. First, just like Grice's theory of meaning, the neo-Gricean theory of interpretation is supposed to be general or universal and not limited to some specific language community or speech situation. This is not only manifest in its application to different types of communicative phenomena but also in its claim to apply across

65. Stalnaker, Context (n 7) 108.

66. Stalnaker, Context and Content (n 7) 98.

67. Clark, Arenas of Language Use (n 7) 62; Stalnaker, 'Common Ground' (n 7) 701; Stalnaker, Context (n 7) 108.

68. Stalnaker, 'Common Ground' (n 7); 704.

69. Interestingly, both Hart and Dworkin seem to be broadly sympathetic to this approach to interpretation:

[W] normally do not only interpret what people are trying to do but what they say in the light of assumed common human objectives so that unless the contrary were expressly indicated we would not interpret an instruction to show a young child a game as a mandate to introduce him to gambling even though in other contexts the word 'game' would be naturally so interpreted.

Hart, 'Positivism and the Separation of Law and Morals' (1958) 71 Harvard Law Review 593, 628. "Like almost all terms the precise meaning of "discretion" is affected by features of the context. The term is always colored by the background of understood information against which it is used'. Dworkin, Taking Rights Seriously (n 9) 31.

70. See, for example, Clark, Arenas of Language Use (n 7). 
different languages and communicative situations. ${ }^{71}$ Second, what an interlocutor presupposes in conversation - what she takes to be common ground - is itself a matter of fact because it is a matter of fact whether someone takes certain information for granted or not. ${ }^{72}$ This raises the question, however, what kind of fact we are talking about when we talk about presuppositions, and this leads me to my last point. Presupposing is a propositional attitude of a speaker or hearer and it is distinctively social or public. It is so because one only presupposes a proposition if one assumes that others do and assumes that others assume one to presuppose it and so on. Importantly, in order to presuppose a proposition, it is neither necessary nor sufficient for a speaker to believe this proposition. That this is so is illustrated by cases where, for instance, one or more participants believe that a certain proposition is false but decide to act as if it was true for the sake of conversation. A standard example is the case where a participant to a conversation at a cocktail party believes that a certain man who is the topic of the conversation is drinking water while the other participants have all expressed the belief that he is drinking a martini. Since not much might turn on what exactly the man is drinking, the participant might not want to interrupt the flow of the conversation and acts as if she believes that the man is drinking a martini. In such a case an assertion such as

(2) The man with the martini is a philosopher

would also work in order to refer to the specific man and to communicate that he is a philosopher, despite the speaker's belief that the man is drinking water. According to Stalnaker, a broader attitude than belief is sufficient for some proposition to be common ground and this attitude is acceptance.${ }^{73}$ In the scenario the speaker and the other participants to the conversation tacitly accept the proposition in the common ground that the man is drinking a martini. On this understanding, accepting a proposition in conversation 'is to treat it as true for some reason' ${ }^{74}$ Further, one should not necessarily understand presupposing as a mental attitude or something that the speaker needs to consciously think about during the conversation or needs to have thought about in the past:

To presuppose a proposition ... does not imply that the person need have any particular mental attitude toward the proposition, or that he need assume anything about the mental attitudes of others in the context. Presuppositions are probably best viewed as complex dispositions which are manifested in linguistic behavior. One has presuppositions in virtue of the statements he makes, the questions he asks, the commands he issues.... The set of all the presuppositions made by a person in a given context determines a class of possible worlds,

71. For criticism of the theory see, for example, Barbara Abbott, 'Presuppositions and Common Ground' (2008) 31 Linguistics and Philosophy 523; John Hawthorne and Ofra Magidor, 'Assertion, Context, and Epistemic Accessibility' (2009) 118 Mind 377. Stalnaker has defended the theory on several occasions against these and other objections. Robert C Stalnaker, 'A Response to Abbott on Presupposition and Common Ground' (2008) 31 Linguistics and Philosophy 539; Robert C Stalnaker, 'On Hawthorne and Magidor on Assertion, Context, and Epistemic Accessibility' (2009) 118 Mind 399; Stalnaker, Context (n 7).

72. '[C]ontext-dependence means dependence on certain facts, but the facts must be available, or presumed to be available, to the participants in the conversation'. Stalnaker, Context and Content (n 7) 98.

73. Stalnaker, 'Common Ground' (n 7) 716.

74. ibid 716. 
the ones consistent with all the presuppositions. This class sets the boundaries of the linguistic situation. ${ }^{75}$

To illustrate this, consider the proposition that there are no unicorns. For someone to presuppose this in conversation it is enough that she acts as if she had this belief even if she does not. For instance, she will not ask others if they have seen a unicorn recently or assert that her unicorn is ill. She might even secretly believe that there are unicorns but as long as this does not manifest itself in her communicative behaviour it will not be presupposed. Moreover, on this account for something to be common ground the specific question does not even need to have been raised in conversation before or thought about by any of the participants. For instance, consider the proposition that there are 53 unicorns. If it is common ground that there are no unicorns, then consequently it will also be common ground that it is false that there are 53 unicorns despite the possibility that no participant has ever actively engaged with this particular proposition. ${ }^{76}$

Having mentioned this, let me turn to the question of how considerations of common ground can be used to explain how hearers can come to disagree about the meaning of a communicative act. Considering that according to this theory interpretation exploits information that is in the common ground, it should be obvious what this explanation is: hearers disagree about the meaning of an utterance because they take different sets of information to form the context against which the utterance was presumed to be understood. Put somewhat differently, they disagree about what the speaker assumed to be the common ground against which her utterance would be interpreted. Neo-Griceans call contexts in which such divergences in background assumptions arise 'defective contexts' and point out that '[d]iscrepancies of this sort are a major source of misunderstanding between people'. ${ }^{77}$ To illustrate how such divergences might cause a disagreement about meaning among hearers, consider a possible scenario in which two hearers, call them Alice and Barbara, might come to disagree about what a speaker Claire meant when uttering (1) ('Peter went to London'). In the scenario, Alice and Barbara each have a friend in common with Claire whose name is 'Peter' but who is not the same person (to avoid further complexity let us assume that they each have only one friend with the name 'Peter' in common with Claire and that there is one salient referent for 'London' in that situation, etc). So, when Claire utters (1) each of them interprets her utterance against two different sets of information, each of them containing a different Peter. And since this information is different, they will interpret Claire's utterance in different ways. Now, there is certainly a fact of the matter as to what Claire meant - which Peter she intended to refer to - and which Peter she presupposed to be the salient referent, but since Alice and Barbara do not have direct access to this presupposed information and they further disagree about what it was that was presupposed, they are bound to arrive at different interpretations and to disagree about what she meant.

75. Stalnaker, Context and Content (n 7$) 38$.

76. However, this only straightforwardly applies to obvious consequences and '[i]n a realistic situation we will have to worry about the obviousness and the salience of the consequence'. Stalnaker, 'Common Ground' (n 7) 709. See also Schiffer (n 7) 36.

77. Stalnaker, Context (n 7) 47; Clark, Arenas of Language Use (n 7) 68. 


\section{A PRAGMATIC EXPLANATION OF INTERPRETIVE DISAGREEMENTS ABOUT LAW}

Building on the insights from the preceding sections, I would now like to spell out how a Hartian view that is informed by a neo-Gricean framework can give a coherent explanation of interpretive disagreements about law. I will call this 'the pragmatic model'. The central point of disagreement between this model and the view endorsed by Dworkin (as well as other commentators such as Leiter and Shapiro) concerns the claim that on Hart's view interpretive disagreements about law - such as the disagreement in Riggs - must be analysed as disagreements about the grounds of law. In order to understand why this is so, we need to remember that Dworkin thinks that Hart is committed to the claim that the meaning of a legal text is determined by means of an interpretive method that is itself a ground of law and therefore conventionally accepted. The pragmatic model rejects this claim because the neo-Gricean framework provides analyses of meaning and interpretation on which it is not a matter of convention what determines the meaning of some communicative contribution, such as a statute, or how the contribution is to be interpreted, i.e. how the meaning is recognized. Instead, the neo-Gricean theory provides analyses of meaning and interpretation that are universal. And since for some rule such as the Rule of Recognition to be conventional it needs to specify actions or conditions that are optional, e.g. a convention that regulates if we should drive on the right or on the left of the road, and matters of meaning and interpretation are claimed not to be optional but universal, on the pragmatic model they are not determined by convention. ${ }^{78}$ Hence, on the pragmatic model the Rule of Recognition - being a conventional rule does not specify what constitutes the meaning of legal texts and how we interpret them. Instead, on this model meaning is universally determined by communicative intentions and interpretation universally proceeds by looking for the speaker's intention in the light of the common ground. On this view, the Rule of Recognition still specifies the texts whose meanings give rise to legal rules but it does not specify what determines the meaning of these texts or how this meaning is to be recognized since this is already taken care of by universal pragmatic arrangements. ${ }^{79}$

78. Lewis (n 64).

79. I take it that this is the possibility that Dale Smith has recently mentioned in passing when discussing Leiter's work:

One could imagine a different version of positivism, which claims that convergence among officials determines only what the sources of law are, and that there is a non-convergencebased way of getting from the sources of law to the content of the law. For example, convergence among officials might determine that statutes are a source of law, but not how statutes are to be interpreted - theories in philosophy of language and linguistics might settle the question of interpretation.

Smith, 'Agreement and Disagreement in Law' (n 3) 189. However, Smith also expresses scepticism about the prospects of such an account: 'I hope to show in future work that, while this view avoids some of the problems with the version of positivism that Leiter defends, it encounters other significant problems'. Smith, 'Agreement and Disagreement in Law' (n 3) 189. In a subsequent publication, Smith has provided an objection to views according to which the legal rules that exist in a legal system are entirely determined by the meaning of legal texts. Dale Smith, 'The Practice-Based Objection to the Standard Picture of How Law Works' (2019) 10 Jurisprudence 502. The objection comes from legal practice and it is that such views cannot account for so-called 'retrospectively operating modifier laws' which are laws that change the legal rules that a text gives rise to after the text has been enacted and acquired its meaning. 
Instead of thinking of interpretive disagreement as a type of theoretical disagreement, the positive proposal of the pragmatic model is to analyse them as empirical disagreements: as disagreements about whether conventionally shared criteria of legal validity are in fact satisfied in the respective cases. The proposed explanation goes as follows. Following Hart, on this account the Rule of Recognition specifies the criteria of legal validity or grounds of law, such as that something is a primary rule of English law if it has been enacted by the Queen in Parliament. Now, when judges disagree about what the enacted primary rule is, because they disagree about the meaning of the enacted text, then the pragmatic model does not see this as an incoherent dispute about some convention that specifies how this text is to be interpreted because this is not determined by convention. Rather than disagreeing about a convention they disagree about a different kind of fact. Their disagreement must be about what the communicative intention is that the legal authority tried to get across. And this disagreement arises because judges disagree about what the legal authority presupposed when it enacted the text. ${ }^{80}$ This is an empirical disagreement because the judges do not disagree about the criteria of legal validity; they agree that for a certain rule to exist it needs to be enacted by the relevant authority. Rather, as result of their disagreement about the meaning of the enacted text they disagree about whether a certain rule has actually been enacted by the authority, and this is an empirical disagreement.

It seems to me that this model is fully consistent with the requirements of a plain-fact view about law because it accounts for the meaning and interpretation of enacted texts in terms of facts, since meaning and interpretation depend on the factual notions of communicative intention and presupposition. Further, I believe that the pragmatic model can also explain why Dworkin has not realized the plain-fact view's ability to account for interpretive disagreements in terms of empirical disagreements. He underestimated the possible complexity that factual disagreements about meaning might have, which manifests itself in his characterization of the plain-fact view as a view on which 'questions of law can always be answered by looking in the books

Unfortunately, Smith does not make explicit if this objection is the kind of problem that he had in mind in his earlier publication. However, irrespective of whether this is the case or not, I do not think that his objection is at odds with my view because (in line with my remarks in (n 6)) I do not hold a view on which a legal rule is exclusively determined by the meaning of a text. For the sketch of a similar view, see Endicott (n 6) para 2.4. Rather, my view is that meaning is an important determinant of legal rules but that it need not be the only one. In particular, other grounds of law (on a Hartian account this might be, for instance, moral values, see (n 23)) or other legal rules, including retrospectively operating modifier laws, can determine which rules exist in a legal system together with the meaning of legal texts. In other words, the pragmatic model neither claims nor needs to claim that the meaning of a text is the only determinant of legal rules in order to provide an explanation of interpretive disagreements.

80. I have to mention at this point that considerations of common ground and presuppositions have already been used by Duarte d'Almeida in an attempt to rebut the ATD. See Duarte d'Almeida (n 3). However, he proposes to do so in a way that is significantly different from mine, namely by suggesting that in cases of theoretical disagreements the judges are presupposing different Rules of Recognition, i.e. they are using different criteria of legal validity. As mentioned before (see ( $\mathrm{n}$ 41)) this account is based on a reading of Hart that has been made prominent by Kevin Toh. According to this reading, convergence on a set of criteria of legal validity is not necessary for a Rule of Recognition to exist and for theoretical disagreements to be coherent. I agree with Leiter that such a reading 'is flatly contradicted by what Hart says' and that Duarte d'Almeida's proposal is unsuccessful. See Leiter, 'Theoretical Disagreements in Law' (n 3) 256, 260-61. Shared agreement about a Rule of Recognition is necessary on Hart's account because primary legal rules could not be validated in the absence of such an agreement. 
where the records of institutional decisions are kept', and his suggestion that the empirical disagreement that judges can engage in are merely about 'what words are in the statute books' ${ }^{81}$ If we take insights from pragmatics on board, then it turns out that this is an extremely limited picture of the different ways in which empirical disagreements about law can arise. Empirical disagreements can also concern what a legal authority meant with the words that it used. Such disagreements can occur because interpretation does not proceed by merely considering the words that are used but also what the words indicate about the communicative intention of the promulgating authority. And in order to figure this out one always has to consider information that goes beyond the conventional meaning of the words. In particular, one has to consider what was presupposed, which is itself a matter of fact. This even applies if the words are understood literally, for even the conventional meaning of words is information that is part of the common ground, as indicated above. Dworkin's failure to take into account that officials might also have an empirical disagreement about legal rules that goes beyond the mere disagreement about what words are in a book demonstrates, I think, that he indeed had an 'impoverished view of the controversy that can result from communication' as Endicott claims. ${ }^{82}$

Before providing an illustration of how the pragmatic model can be used to explain real-life cases of interpretive disagreement, I first want to defend the model against what I take to be the three most pertinent objections that might be raised against it. The first objection has to do with the reason why theorists believe that the Rule of Recognition must specify a conventional method of legal interpretation, namely its function to remove uncertainty about the primary legal rules that exist in a legal system. Since the pragmatic account rejects this claim and relies on a nonconventional account to determine meaning and interpretation, one might worry if this will not lead to excessive uncertainty about primary legal rules. More specifically, one might argue that the fact that judges might consider different information to be part of the common ground to be a major source of uncertainty about the meaning of legal texts and consequently also about legal rules. I would like to dispel this worry by making three points. First, as already explained above with reference to Hart's own remarks, the Rule of Recognition does not need to remove all uncertainty about the legal norms that hold in a legal system in order to serve its function of providing legal officials with a guide to existing legal norms. It would therefore not be correct to claim that the Rule of Recognition fails in its function if it does not remove all uncertainty about legal norms. Second, the uncertainty that the pragmatic model allows for is by no means unlimited. The fact that only information that can reasonably be claimed to be shared is considered to be part of the context strictly limits the range of information that can be invoked to support a certain interpretation and thereby also the range of available interpretations. Finally, I do not see any reason to believe that methods such as textualism or intentionalism which are taken by commentators to provide a sufficient degree of certainty would necessarily lead to more certainty overall than the

81. Dworkin, Law's Empire (n 1) 7, 5.

82. Endicott (n 6) para 2.4. Dare has made a similar point when saying that 'Dworkin's account of empirical disagreements ... is unconvincing' because 'empirical disagreements about legislative intent might lead judges to disagree about what "the real statute the judges [sic] enacted, or the real decisions binding courts issued really said." Dare (n 3) 9. However, he doubts that this can explain the disagreement in Riggs because judges allegedly did not only invoke legislative intent but also literal meaning and further principles as grounds of law. Below I will try to show that this can be explained by my account, as well, by using considerations of context. 
neo-Gricean account of interpretation. For if one claims that only literal meaning should be considered to determine the meaning of a legal text then one will be faced with the problem that this meaning will not be sufficient to provide a guide to a large number of legal questions because literal meaning - to the extent that it can provide a determinate meaning at all - always leaves open a broad variety of possibilities which will not suffice to determine clear legal results in many cases. ${ }^{83}$ The same goes for intentionalism. If the method is simply to consider the (non-communicative) intentions that a legal authority might have had in relation to an enactment or decision then this will allow for a lot of speculation about what this intention was and what it requires in a specific case. ${ }^{84}$ Hence, it does not seem at all clear that on a neo-Gricean account of interpretation judges would have less guidance about primary legal norms than if they had adopted a textualist or intentionalist method. And if these methods are considered by commentators to provide a sufficient amount of certainty to account for the purpose of the Rule of Recognition then there does not seem to be any evident reason to believe that interpretation according to a neo-Gricean account could not account for this purpose, as well.

Another possible objection might target the assumption of the pragmatic model that collective bodies such as legislatures can and do have communicative intentions. In fact, Dworkin himself has famously argued - although not in relation to the ATD and without mentioning (neo-)Gricean theories - that the meaning of statutory language cannot be analysed in terms of intentions because legislative bodies are characteristically collective agents and (according to him) such agents are incapable of having intentions. ${ }^{85} \mathrm{He}$ argued further that even if they could have intentions, their intentions would not have any determinate content because it is unclear how the often diverging intentions of different legislators with respect to a statute can combine into such a collective intention. However, I do not think that this objection should worry us too much for at least two reasons. First, the sceptical view towards legislative intent has recently been convincingly criticized by Richard Ekins in his book The Nature of Legislative Intent. ${ }^{86}$ Ekins argues that sceptics such as Dworkin mistakenly assume that an account of legislative intent must treat collective intentions as aggregates of the individual intentions of legislators, and fail to consider the alternative possibility that legislative bodies might be able to form collective intentions that do not need to be understood as the sum of the individual intentions of their members. Ekins goes on to develop an account of legislative intentions that is not committed to this assumption but rather explains them in terms of so-called joint intentions which are plans of action that coordinate and structure the action of the group. These plans allow the legislature to have determinate intentions and Ekins even claims that legislatures can - and do have communicative intentions à la Grice.

The second reason why I think that we should not be too worried about criticisms of the possibility of legislative intentions is that even if we should be left unconvinced by Ekins' account, it seems that a look at the recent outpouring of work on collective

83. Emma Borg, Minimal Semantics (Oxford University Press 2004); Francois Recanati, Literal Meaning (Cambridge University Press 2004); Bart Geurts, 'Convention and Common Ground' (2018) 33 Mind \& Language 115.

84. Scalia (n 35).

85. Dworkin, Law's Empire (n 1) ch 9. See also Michael S Moore, 'The Semantics of Judging' (1981) 54 Southern California Law Review 151; Heidi M Hurd, 'Sovereignty in Silence' (1990) 99 Yale Law Journal 945; Jeremy Waldron, Law and Disagreement (Clarendon Press 1999) ch 6. 86. Ekins (n 6). 
intentionality in social ontology suggests that the view that legislative intentions cannot exist is outdated. ${ }^{87}$ Rather, it appears that there is no shortage of accounts of collective intentionality which makes it acceptable to assume that collectives such as legislatures might be intentional agents. ${ }^{88}$ In the face of the ongoing debate in social ontology concerning the correct way of accounting for collective intentions, here I do not want to commit myself to any particular view, but only point out that the multitude of available accounts shows that there is nothing unrespectable about the assumption that legislatures can and do have intentions, including communicative intentions.

One last objection that I would like to consider has to do with considerations of incoherence. We might recall at this point that what made theoretical disagreements problematic for Hart was that they are disagreements about a kind of fact that one cannot persistently and coherently disagree about, namely conventions. Such disagreements would be incoherent because conventions must be shared. Now, one might argue that the pragmatic model runs into a very similar problem of incoherence because it claims that interpretive disagreement results from a disagreement about a kind of fact about which there cannot be any coherent disagreement either, namely the common ground. One would argue that since the common ground is supposed to be shared, a dispute among judges about whether some information is common ground would also be incoherent because judges would have to conclude that this information cannot be common ground, exactly because it is disputed. ${ }^{89}$

However, I think that this objection would be unsuccessful because I do not claim that judges disagree about whether some information is common ground in legal discourse but rather about whether the speaker - in this case the legal authority - took the information to be common ground. It is the presuppositions of the speaker that are important because it is these presuppositions against which she tried to get her communicative intention across. As the example of (1) illustrated, what is relevant in determining what a speaker means is not what the common ground of the conversation is but rather what the speaker took it to be. And while it might be true that there cannot be coherent disputes about the common ground, it is not true that disputes about what a speaker took to be common ground are incoherent. Exactly because what the speaker presupposed does not have to be presupposed by her interlocutors it is coherent for her interlocutors to disagree about what she presupposed. This is the reason why the pragmatic model does not run into the same problem of incoherence as an account on which interpretive disagreements are treated as disagreements about conventional practice.

Having discussed what I take to be the most pertinent objections to the pragmatic model, in the rest of this section I would like to discuss how the pragmatic model might explain actual cases of interpretive disagreement by applying it to Riggs. Now,

87. For criticism of Ekins's account, see, for example, Dimitrios Kyritsis, 'Intending to Legislate' (2015) 78 Modern Law Review 164. For a survey of recent work on collective intentionality, see David P Schweikard and Hans Bernhard Schmid, 'Collective Intentionality' The Stanford Encyclopedia of Philosophy (Summer edn, 2013) <https://plato.stanford.edu/ archives/sum2013/entries/collective-intentionality/> accessed 15 July 2020.

88. See, notably, John Searle, 'Collective Intentions and Actions' in Philip R Cohen, Jerry Morgan and Martha E Pollack (eds), Intentions in Communication (Bradford Books, MIT Press 1990); Margaret Gilbert, Joint Commitment: How We Make the Social World (Oxford University Press 2014); Michael E Bratman, Shared Agency: A Planning Theory of Acting Together (Oxford University Press 2014).

89. Lars Vinx has objected along these lines to an earlier version of this paper and I am very grateful to him for pressing me on this point. 
having read Dworkin's characterization of the case, one's immediate reaction might be that the pragmatic model is doomed to fail to explain the dispute between Judge Gray and Judge Earl. For if we consider that Gray allegedly insisted that "the words of a statute [should] be given what we might ... call their acontextual meaning, that is, the meaning we would assign them if we had no special information about the context of their use or the intentions of their author' and that 'no context-dependent and unexpressed qualifications be made to the general language ...' it might seem as if Gray refused to consider information about context or intentions, including communicative intentions. ${ }^{90}$ This would be at odds with the pragmatic model because it would show that judges' interpretive behaviour is inconsistent with neo-Gricean claims about meaning and interpretation. However, I think that it would be inaccurate to think of Gray's opinion in this way. Although it is true that Gray primarily focused on literal meaning, he never explicitly talked about context, let alone generally refused to consider it, and also never generally refused to consider information about intentions. It is correct that he refused to consider speculation about mere intentions of testators as sufficient to revoke their own wills but this was not the point of dispute in Elmer's case. ${ }^{91}$ As Dworkin recognizes, the dispute was about how the statutes of wills were supposed to be interpreted and Gray never said that he refused to consider the intentions of legislators in the interpretation of these statutes. That he did not generally refuse to consider legislative intentions is further supported by Leiter's observation that when deciding other cases Gray was not opposed at all to the consideration of intentions or other information that goes beyond literal meaning. ${ }^{92}$ Further, the acceptance of context and at least some kinds of intentions seems to hold more generally for proponents of literalist or textualist interpretations. Even dyed-in-thewool textualists, such as Antonin Scalia, claim that '[i]n textual interpretation, context is everything ...' and accept that judges 'look for a sort of "objectified" intent - the intent that a reasonable person would gather from the text of the law ...'. ${ }^{93}$ Based on an analysis of textualist opinions, Stephen Neale has recently argued that the 'objectified intent' that textualists are looking for in their opinions is best understood as a Gricean communicative intention. ${ }^{94}$ Hence, it appears to be incorrect to say that Gray or other textualists do not recognize communicative intentions or context in the interpretation of the law. Rather, despite certain appearances, it seems that it is exactly what they are looking for. ${ }^{95}$

90. Dworkin, Law's Empire (n 1) 17, 17-18.

91. Riggs (n 8) 517.

92. Leiter, 'Explaining Theoretical Disagreement' (n 3) 1242-46. While Leiter takes this to be a demonstration of the disingenuousness of judges in interpretation, the pragmatic model explains these differences in terms of a judge's emphases on different aspects of the common ground in different cases. If correct, the pragmatic model would be able to explain the data without accusing judges of disingenuousness or error and therefore provide a more charitable account of judicial practice than Leiter which - I take it - would make it superior to his account from a methodological point of view.

93. Scalia (n 35) 37, 17 (emphasis added).

94. Neale (n 6). See also Ekins (n 6) 203-05; and Nicholas Allott and Benjamin Shaer, 'Inference and Intention in Legal Interpretation' in Janet Giltrow and Dieter Stein (eds), The Pragmatic Turn in Law: Inference and Interpretation in Legal Discourse (De Gruyter Mouton 2017) 113-14.

95. One might object now that there are certain textualists who do occasionally speak as if they do not consider intentions of legislators at all and insist that they only consider the plain meaning of the text (for instance, Scalia himself occasionally makes claims that might be associated with 
However, in order to explain the disagreement in terms of pragmatics we do not only have to show that an opinion considers communicative intentions and common ground in legal interpretation but also that the disagreement about meaning can be plausibly explained as resulting from a defective context. In order to do so it must be shown that the diverging sets of information that judges appeal to can reasonably be claimed to have been presupposed by the legal authority. Can we say this about Gray's primary focus on literal meaning? It is my contention that we can. It does not seem to be unjustified for a judge to claim that nothing but the most general information constitutes the background of legal discourse because it is a form of mass communication. That is, the participants to legal discourse usually constitute a very large and diverse group whose members do not know each other personally which suggests that they are unlikely to share a lot of information. This justifies the assumption that the information in the common ground that is probably most salient and relied upon by legislators is simply the information about the conventional meaning of the words and grammar of a language, because mastery of a language is presupposed by everyone who engages in legal discourse simply because it uses the language as a tool of communication. Hence, it can be plausibly assumed that legislators will mainly rely on this type of information to have their communicative intention recognized and refrain from presuming specific information about noncommunicative intentions that is unlikely to be shared. In support of this I would like to mention that although I disagree with Dworkin's characterization of Gray's method, I still think that there is a grain of truth in it, because he importantly says that a literalist interpretation of statutes rejects 'special information about the context of their use or the intentions of their author'. ${ }^{96}$ The reason why literalists refuse to consider such special information is that such special information is less likely to be shared by the participants to legal discourse than general information, such as literal meaning. For these reasons, I claim that Gray's interpretation is accurately described as an appeal to communicative intentions and common ground.

How about Earl's interpretation? Is it accurately described as an attempt to recognize the communicative intention of the New York authorities by reading the statutes of wills in the light of shared information? The following passage from his opinion is instructive:

What could be more unreasonable than to suppose that it was the legislative intention in the general laws passed for the orderly, peaceable and just devolution of property, that they should have operation in favor of one who murdered his ancestor that he might speedily come

this view: 'It is the law that governs, not the intent of the lawgiver' Scalia (n 35) 17 (emphasis in original)). However, I think that this can be accounted for by the distinction between communicative and non-communicative intentions because it is likely that what these textualists are referring to are intentions of the non-communicative and not the communicative kind. This seems plausible because people - including judges - are usually neither aware that meaning is analysed in terms of a communicative intention nor familiar with the concept of a communicative intention more generally (if they were, then Grice's analysis of meaning would not have been an interesting discovery). Since they are not familiar with this it is likely that what they have in mind when talking about intentions is a less complex notion of intention which, by definition, is non-communicative. They have in mind, for example, that by enacting a certain tax law the legislature intended to support low-income families or that by introducing high toll charges it intended to keep foreign freight out of the country. But since these intentions are not communicative, textualists' disregard of them is not a threat to the pragmatic model.

96. Dworkin, Law's Empire (n 1) 17 (emphasis added). 
into the possession of his estate? Such an intention is inconceivable. We need not, therefore, be much troubled by the general language contained in the laws. ${ }^{97}$

This reasoning can be explained from a neo-Gricean perspective, as well. Earl argues here that the effect that legislators intended could not have been that murderers are allowed to inherit because he considers this to be inconceivable. Further, it is claimed to be inconceivable because it would clash with the assumed purpose of the statutes of wills to enable the 'orderly, peaceable and just devolution of property'. It does not appear misplaced to me to say that Earl appeals to this general purpose of the statute because he takes it to be obvious that lawmakers presupposed this purpose when passing the statutes of wills. In neo-Gricean terms: I think it is fair to say that Earl argues that the meaning of the statutes of wills must be recognized against this manifest purpose of the statutes of wills because it was taken for granted. Furthermore, Earl claims that the inconceivability of the intention to let murderers inherit overrides the 'general language' of the statutes of wills. This also fits nicely with the pragmatic model according to which what is taken for granted 'sets the boundaries of the linguistic situation'. ${ }^{98}$ The situation here is such that presupposed inconceivability of an authoritative intention that allows murderers to inherit limits the general applicability of the literal meaning of the text of the statute.

Finally, I think that the second central consideration in Earl's interpretation, namely that statutes of wills should be interpreted in the light of the principle that no one should profit from his own wrong, can also be accounted for by the pragmatic model. On this model, Earl takes this principle to be presupposed by the legal authority and therefore to be part of the context against which the statutes of wills need to be interpreted. This reading of Earl's opinion is even supported by Dworkin himself when he describes Earl's approach as one on which 'the court cited the principle that no man may profit from his own wrong as a background standard against which to read the statute of wills and in this way justified a new interpretation of that statute'. ${ }^{99}$ Further, Earl himself made explicit that he took the principle to be presupposed by the lawmaker when he said that '[ $\mathrm{t}]$ his is not a casus omissus. It is evidently supposed that the maxims of the common law were sufficient to regulate such a case and that a specific enactment for that purpose was not needed'. ${ }^{100}$ Consider also the following passage from Earl's opinion:

97. Riggs (n 8) 511.

98. Stalnaker, Context and Content (n 7) 38.

99. Dworkin, Taking Rights Seriously (n 9) 45 (emphasis added).

100. Riggs (n 8) 513 (emphasis added). Dimitrios Kyritsis objects to me that Earl's claim that the 'maxims of the common law were sufficient to regulate such a case and that a specific enactment for that purpose was not needed' suggests another reading of the dispute about the status of principles in Riggs. On this reading, the principle that nobody shall profit from his wrong is not merely a contextual assumption that affects the meaning of statutes and other legal sources but is rather a self-standing legal norm that can regulate the case independently from other primary legal norms. However, I think that this passage can arguably also be understood as saying that an explicit enactment was not needed exactly because the principle is sufficient to limit the meaning of already existing statutes as a contextual assumption. Similar things can be said about other passages from Earl's opinion that might be thought to point towards the alternative reading suggested by Kyritsis, for instance when Earl says that 'all laws as well as all contracts may be controlled in their operation and effect by general, fundamental maxims of the common law' or that ' $[\mathrm{t}]$ hese maxims, without any statute giving them force or operation, frequently control the effect and nullify the language of wills'. Riggs (n 8) 511, 512. Instead of 
No one shall be permitted to profit by his own fraud, or to take advantage of his own wrong, or to found any claim upon his own iniquity, or to acquire property by his own crime. These maxims are dictated by public policy, have their foundation in universal law administered in all civilized countries, and have nowhere been superseded by statutes. ${ }^{101}$

Given that he claims that the maxims are universally accepted by the legal systems of 'all civilized countries' without having been made explicit in statutes it seems fair to say that he appeals to the common-sensical status of these principles and thereby to the claim that they are presupposed by the legislature. Hence, again, it seems that we can plausibly explain Earl's appeal to a general principle of law as an appeal to the context against which the meaning of the statutes of wills must be recognized.

\section{CONCLUSION}

The aim of this article was to provide a Hartian explanation of a certain type of disagreement among judges that Dworkin considered to be a type of theoretical disagreement about law: interpretive disagreements. I have tried to do so by drawing on work from pragmatics that explains disagreements about meaning as disagreements about the communicative intentions of legal authorities which result from divergences in assumptions about what these authorities presupposed. I have argued that this explanation can show that the interpretive disagreements that are invoked by Dworkin do not pose a threat for Hart because they do not need to be explained as disagreements about the grounds of law but rather as disagreements about whether certain primary rules have been enacted. In order to illustrate how my account explains actual cases of interpretive disagreement I have applied it to the famous case of Riggs. To what further extent the model can be useful for Hartian positivism when facing the ATD will depend - among other things - on whether it can also explain other cases in which theoretical disagreement supposedly occurred.

interpreting these as claims to the effect that the maxims of the common law are self-standing legal norms, one can also reasonably understand them as contextual assumptions that limit the applicability of the 'language' of statutes, wills and contracts.

101. Riggs (n 8) 511-12. 